\title{
O6-Methylguanine-DNA methyltransferase protein expression by immunohistochemistry in brain and non-brain systemic tumours: systematic review and meta-analysis of correlation with methylation-specific polymerase chain reaction
}

\author{
Marta Brell ${ }^{1 *}$, Javier Ibáñez ${ }^{1}$, Avelina Tortosa²
}

\begin{abstract}
Background: The DNA repair protein $0^{6}$-Methylguanine-DNA methyltransferase (MGMT) confers resistance to alkylating agents. Several methods have been applied to its analysis, with methylation-specific polymerase chain reaction (MSP) the most commonly used for promoter methylation study, while immunohistochemistry (IHC) has become the most frequently used for the detection of MGMT protein expression. Agreement on the best and most reliable technique for evaluating MGMT status remains unsettled. The aim of this study was to perform a systematic review and meta-analysis of the correlation between IHC and MSP.

Methods: A computer-aided search of MEDLINE (1950-October 2009), EBSCO (1966-October 2009) and EMBASE (1974-October 2009) was performed for relevant publications. Studies meeting inclusion criteria were those comparing MGMT protein expression by IHC with MGMT promoter methylation by MSP in the same cohort of patients. Methodological quality was assessed by using the QUADAS and STARD instruments. Previously published guidelines were followed for meta-analysis performance.

Results: Of 254 studies identified as eligible for full-text review, 52 (20.5\%) met the inclusion criteria. The review showed that results of MGMT protein expression by IHC are not in close agreement with those obtained with MSP. Moreover, type of tumour (primary brain tumour vs others) was an independent covariate of accuracy estimates in the meta-regression analysis beyond the cut-off value.

Conclusions: Protein expression assessed by IHC alone fails to reflect the promoter methylation status of MGMT. Thus, in attempts at clinical diagnosis the two methods seem to select different groups of patients and should not be used interchangeably.
\end{abstract}

\section{Background}

The cellular protein $\mathrm{O}^{6}$-Methylguanine-DNA methyltransferase (MGMT) is a DNA-repair protein that removes mutagenic and cytotoxic adducts from $\mathrm{O}^{6}$-guanine in DNA. Alkylating agents are among the most widely used chemotherapeutic drugs in human cancer. Alkylation induced by these compounds can produce

\footnotetext{
* Correspondence: m.brell@telefonica.net

'Department of Neurosurgery, Son Dureta University Hospital, Palma de Mallorca, Spain

Full list of author information is available at the end of the article
}

either lethal double-strand cross-links, as is the case with bifunctional nitrosoureas (BCNU), or induce mismatch abortive repair and DNA fragmentation, as is the case with temozolomide [1-4]. The toxicity of alkylating agents is reduced in the presence of MGMT. Thus, MGMT confers resistance to alkylating agents in a wide spectrum of human tumours by reversing DNA toxicity. In brain neoplasms, hypermethylation of CpG islands in the $M G M T$ gene promoter region, rather than mutation or deletion, is the major mechanism for the loss of MGMT function [2,5-7]. As a consequence, tumours
C Biomed Central

() 2011 Brell et al; licensee BioMed Central Ltd. This is an Open Access article distributed under the terms of the Creative Commons Attribution License (http://creativecommons.org/licenses/by/2.0), which permits unrestricted use, distribution, and reproduction in any medium, provided the original work is properly cited. 
with epigenetic silencing of MGMT gene become more sensitive to the killing effects of alkylating agents. Moreover, several studies have demonstrated that epigenetic silencing of MGMT is a relevant prognostic factor in patients with glioblastoma, anaplastic glioma and low grade glioma [8-14]. In fact, MGMT status has recently been recommended as a stratifying factor for patients in glioma trials $[15,16]$.

Many methods and protocols have been applied for MGMT analysis in gliomas, but to date there is no consensus on which strategy should be primarily employed [17]. Methylation-specific polymerase chain reaction (MSP) is the most commonly used test [9]. Indeed, in glioblastoma clinical trials, a strong correlation of the methylation status of $M G M T$ with temozolomide response and patient outcome was shown. However, there are some methodological problems that limit the usefulness of this method in a routine diagnostic setting: it is complex, time-consuming, and highly dependent on tissue quality $[18,19]$. MGMT status can also be assessed by analyzing protein expression by immunohistochemistry (IHC). IHC is a reliable, commonly used method in diagnostic histopathology that is available in most laboratories. In addition, IHC is easier to use, less expensive and faster than MSP [20-29], and consequently it has become the most frequently used method for the detection of MGMT protein expression in the past decade [30]. In this line, some retrospective clinical reports have also shown a prognostic association between MGMT protein expression and/or activity and outcome.

However, studies aimed at evaluating the correlation between aberrant promoter methylation and loss of protein expression have yielded contradictory results, not only in brain tumours but also in other neoplasms. While we and other authors have shown that the relationship between MGMT promoter methylation status and MGMT protein expression is not absolute [31], other studies have found a strong correlation between homogeneous immunoreactivity and unmethylated promoter [32]. At present, there is a lack of data on which to base recommendations for a specific method or protocol for MGMT testing. Accordingly, there is a strong need for systematic comparisons and validation of intraand interlaboratory reproducibility of different methods for MGMT assessment in order to identify the best method for clinical MGMT testing [33].

The aim of this study was to perform a systematic review and a meta-analysis of the correlation between MGMT IHC and MSP in a large array of human brain and non-brain systemic tumours. Our primary objective was to assess the diagnostic accuracy of IHC at different cut-off values for test positivity. Because test accuracy is not a fixed property of a test [34], we have also studied several possible sources of heterogeneity such as subgroups of patients, differing interpretations of results, and study design features.

\section{Methods}

This systematic review and meta-analysis was performed following previously published guidelines [34-37].

\section{Literature Search}

A computer-aided search of MEDLINE (1950-October 2009), EBSCO (1966-October 2009) and EMBASE (1974October 2009) was performed for relevant publications. Medical Subject Heading (MeSH) terms with accompanying entry terms were used (Additional file 1). To identify additional published, unpublished and ongoing studies, we entered relevant studies identified from the above sources into PubMed and then used the Related Articles function. The Science Citation Index was searched to identify articles citing relevant publications. The reference lists of all selected papers were also reviewed for search completion. Only English-language literature was considered eligible. Titles and abstracts were screened by two reviewers (M.B. and J.I.) to identify relevant articles. Discrepancies were resolved by consensus.

\section{Criteria for inclusion of studies}

Studies meeting inclusion criteria were those comparing MGMT protein expression by IHC with MGMT promoter methylation by MSP as the reference test in the same cohort of patients. Not only brain tumour series but also others involving any type of cancer were considered eligible whenever both diagnostic tests were used in the same population. Studies on cellular lines were excluded. Information had to be available to allow the construction of the diagnostic two-by-two table with its four cells: true positive, false negative, false positive and true negative.

\section{Index test and reference test}

IHC performed with different commercially available antibodies was the test under evaluation and MSP was considered the reference test, as it is the most commonly used.

\section{Quality assessment and data extraction}

Methodological quality of included studies was assessed independently by two observers (M.B. and J.I.) using the QUADAS tool [38] which was specifically developed for systematic reviews of diagnostic test accuracy studies. The tool is based on 14 items scored as "yes", "no", or "unclear". The items from the QUADAS tool and their interpretation can be found in Additional file 2.

Data extraction was performed independently by two authors (M.B. and J.I.), and included author and date, 
journal of publication, time of data collection, testing procedure, study population, reference test, performance of the reference test and of the index test, cut-off value used for immunolabeling, QUADAS-items, whether histological analysis of the tissue used for DNA extraction was performed or not, the percentage of methylated cases by MSP, the effect of methylated promoter/protein expression on survival, and data for two-by-two table. A quality score was not used as a weighting variable because of its subjectivity [39]. The STARD [40] checklist and flow diagram were also followed as recommended.

\section{Data analysis}

Studies reporting insufficient data for the construction of a two-by-two table were excluded from final analyses. Data from the two-by-two tables were used to calculate sensitivity, specificity and diagnostic odds ratio for each study. We present individual study results graphically by plotting the estimates of sensitivity and specificity (and their 95\%CI) in both forest plots and the receiver operating characteristic (ROC) space. Heterogeneity was investigated in the first instance through visual inspection of the relationship between pairs of accuracy estimates in forest plots and sROC space [41]. As one of the primary causes of heterogeneity in test accuracy studies is the threshold effect, which arises when different cut-offs are used in different studies to define a positive (or negative) test result, the computation of the Spearman correlation coefficient between the logit of sensitivity and logit of 1-specificity was also performed. A strong positive correlation suggests this threshold effect. In order to explore for heterogeneity other than threshold effect, the chi-square and Cochrane-Q tests were used. A low p-value suggests the presence of heterogeneity beyond what could be expected by chance alone. The inconsistency index (I-squared) was used to quantify the amount of consistency-that is, the percentage of total variation across studies due to heterogeneity rather than chance. Statistical heterogeneity can be defined as low, moderate and high for $I^{2}$ values of $25 \%, 50 \%$ and $75 \%$ [42]. When a substantial heterogeneity was found, the reasons for it were explored by relating study level covariates to diagnostic odds ratio, using meta-regression techniques. Subgroup analyses trying to identify homogeneity were then performed but in all cases pooling was done using methods based on a random effect model. This model assumes that in addition to the presence of random error, differences between studies can also result from real differences between study populations and procedures, and it includes both within-study and between-study variations. Sensitivity and specificity were compared between these subgroups using the $\mathrm{z}$ test [36]. Publication bias was examined by construction of a funnel-plot. The $\mathrm{x}$-axis consisted of the natural logarithm of the diagnostic odds radio, and the $y$-axis was the standard error, which is considered the best choice [43]. In the absence of bias the graph resembles a symmetrical inverted funnel because the accuracy estimates from smaller studies scatter more widely at the bottom of the graph, with the spread narrowing with increasing accuracy among larger studies. If there is publication bias the funnel plot will appear skewed and asymmetrical. Although useful, interpretation of the funnel-plot is subjective; for this reason the Egger's regression test became necessary in order to measure the funnel-plot asymmetry numerically [44]. The intercept provides a measure of the assymetry: the greater its deviation from zero the more pronounced the asymmetry.

Statistical analysis was performed using Meta-Disc software http://www.hrc.es/investigacion/metadisc_en. htm[45]. The analysis for publication bias was performed using CMA-1 http://www.Meta-Analysis.com. Two-sided $P<.05$ was considered to be statistically significant.

\section{Results}

\section{Results of the search and study characteristics}

The initial search strategy yielded 812 articles, 254 of which were eligible for full-text review. Of these, 182 studies were ruled out, and 72 were selected for data extraction. All selected studies were diagnostic cohort studies. Seventeen studies [20,26,30,46-59] reported data that were insufficient for the construction of the twoby-two table, and in 3 studies [60-62] protein expression was assessed by a test other than IHC. These 20 studies were not included in the analysis. Thus, 52 relevant studies constitute the basis of this analysis (17 glioma studies, 3 non-glioma brain tumour studies and 32 nonbrain systemic tumour studies) comprising a total of 2,943 patients: 539 with primary brain tumours, 178 with brain metastases of various solid tumours and 2,226 with non-brain systemic cancer (Figure 1). Additional file 3 and Additional file 4 show the characteristics of included studies.

Regarding the IHC analysis, the most commonly used antibody was anti-MGMT mouse monoclonal clone MT3.1 (from Dako, Chemicon International, NeoMarkers, Santa Cruz Biotechnology or Kamiya Biomedical Laboratories), which was reported in 39 out of 52 (75\%) studies, followed by anti-MGMT mouse monoclonal antibody clone MT23.2 (from Zymed Laboratory) which was used in $4(7.6 \%)$ series. Other commercially available anti-MGMT antibodies were reported in 7 (13.4\%) additional studies. In one study, no laboratory specification was reported [63]. MGMT immunoexpression was qualitatively analyzed in 16 out of 52 (30.8\%) studies. 


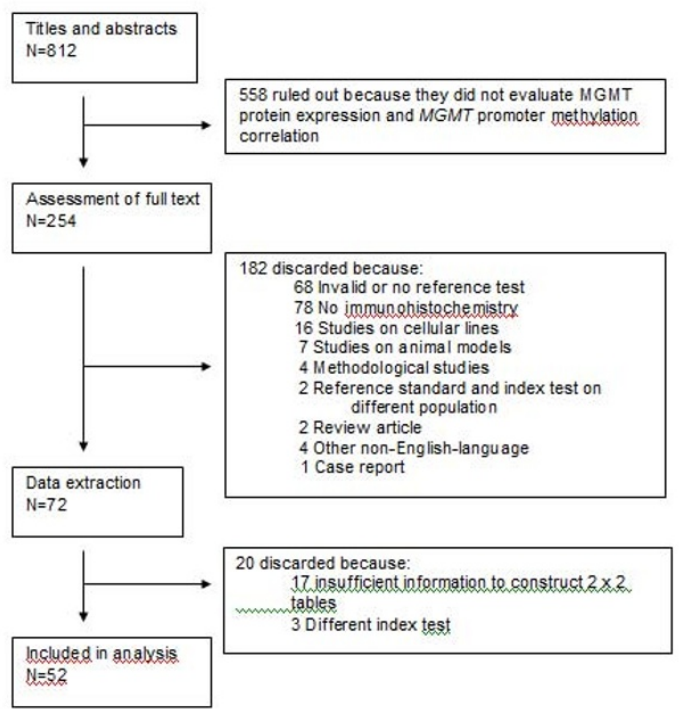

Figure 1 Flow diagram of inclusion process

Accordingly, a semiquantitative score which estimates the fraction of positive cells was used in 36 studies (69.2\%). Indeed, MGMT expression was evaluated by semiquantitative scoring in the majority of the brain tumour studies (18 out of 20) and in 18 out of 32 systemic tumour series. As shown in Additional file 3 and Additional file 4, different cut-off values were used, ranging from $5 \%$ to $80 \%$. Statistically significant association between IHC and MSP was found in 9 out of 20 brain tumour studies, while in the group of non-brain systemic tumours this concordance between the two tests was observed in 29 of the 32 series (90.6\%).

Regarding the MSP analysis, genomic DNA was isolated from formalin-fixed paraffin-embedded tissue in 26 studies (50\%), whereas in 21 cases it was isolated from fresh-frozen samples (40.3\%). In five studies (9.6\%) DNA was isolated from both types of specimens. Sodium bisulfite modification of isolated DNA was performed using commercially available DNA methylation kits in nearly half of them (24 out of 52) including DNA Methylation Kit (Zymo Research), Methylamp DNA Modification Kit (Epigentek Inc), CpGenome DNA Modification Kit (Intergen), and Fast DNA Modification Kit (Chemicon).

\section{Methodological quality of included studies}

Figure 2 and Additional file 5 show assessment of methodological quality of included studies using the QUADAS tool. Inclusion of a representative patient spectrum and explanation of selection criteria or withdrawals did not constitute a limitation of any study. Eight studies reported the use of some modification of the original

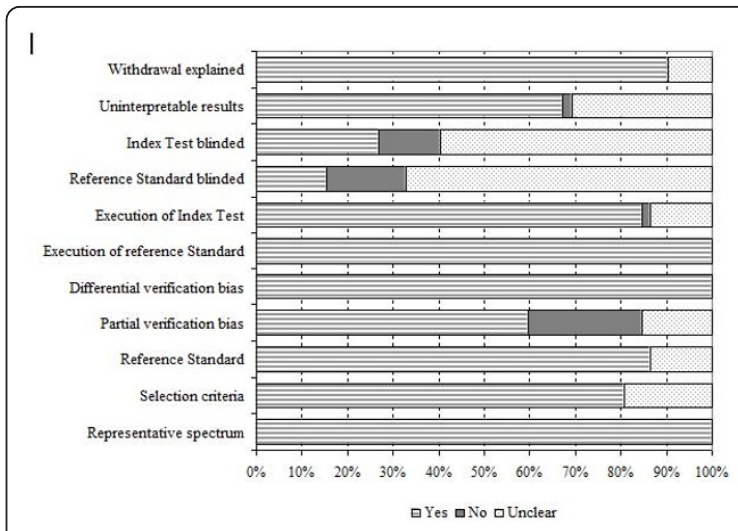

Figure 2 Methodological quality graph.

MSP as the reference test [32,64-70]. In approximately one quarter of the studies, partial verification bias was not clearly avoided as not all cases evaluated with the index test were verified using the reference test. Some authors reported that only tumour samples with an estimated tumour cell content of at least $80 \%$ were used for molecular studies [71], while in others this requirement was not clearly reported.

Immunohistochemical expression was scored semiquantitatively or qualitatively in all but six studies $[1,64,69,72-74]$, in which interpretation of the index test was not satisfactorily explained by the authors. We did not expect any differential verification bias because all studies used the same reference test for the whole cohort of patients. In $84.6 \%$ of the studies, the authors did not unequivocally state whether assessment of the reference test was blinded for the IHC results, and in $73 \%$ of the series, no details were reported about blinding of the index test. Seventeen studies reported no details about any uninterpretable or indeterminate index test results $[2,64,66,70,73-85]$.

\section{Data analysis}

Tabular results for sensitivity, specificity, likelihood ratios and diagnostic odds ratios for all studies are given in Additional file 6. At this early stage of the analysis, the pooled summary of accuracy measures was not taken into account, as significant heterogeneity was suggested when observing the forest plots and the sROC space (Figures $3 \mathrm{~A}$ and $3 \mathrm{~B}$ ). No statistically significant difference was observed when exploring for threshold effect, either considering all studies $(n=52$, Spearman correlation coefficient $=-0.022 ; \mathrm{p}=0.881$ ) or just the subgroup of studies in which semiquantitative scoring was used $(\mathrm{n}=36$, Spearman correlation coefficient $=$ 0.037; $\mathrm{p}=0.833$ ). However, statistical heterogeneity was observed for sensitivity (chi-square $=234.28 ; \mathrm{df}=42(\mathrm{p}$ $<0.0001$ ), inconsistency $\left(\mathrm{I}^{2}\right)=79.5 \%$ ), specificity (chi- 
A.
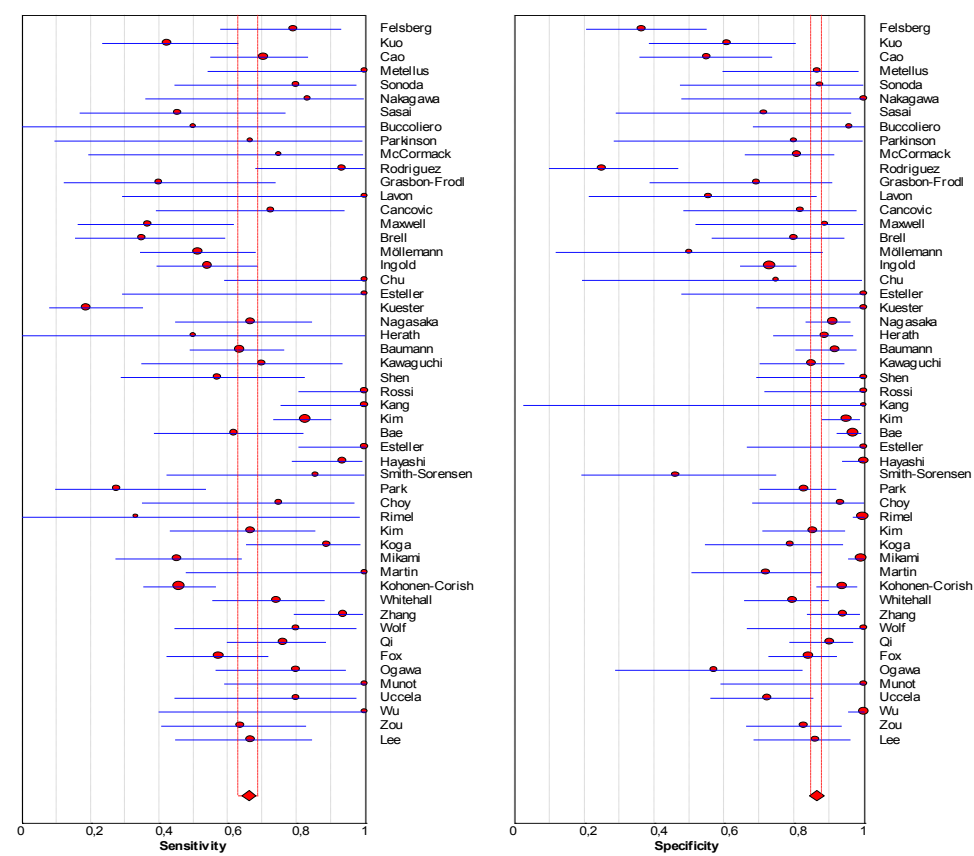

B.

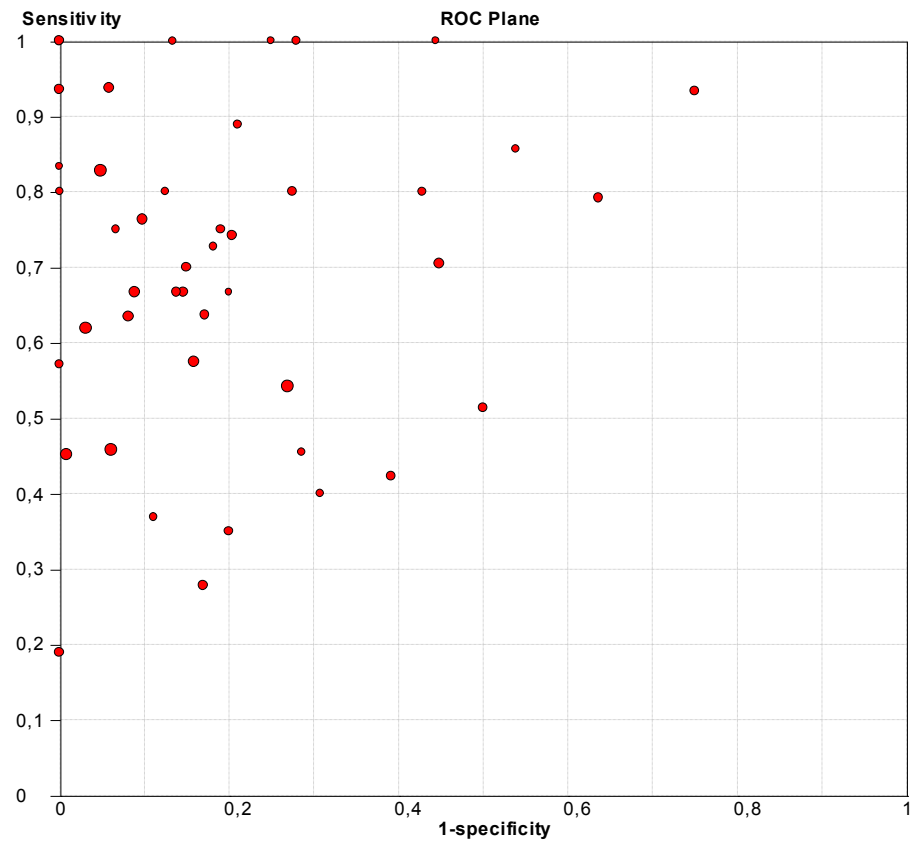

Figure 3 Forest-plots for sensitivity and specificity and ROC Space representation from all elegible studies. (A) Forest-plots for sensitivity and specificity with corresponding 95\% Cl. (B) ROC Space representation of sensitivity against (1-specificity) for each study.

square $\left.=300.84 ; \mathrm{df}=48(\mathrm{p}<0.0001), \mathrm{I}^{2}=84 \%\right)$, positive LR (Cochrane-Q = 265.33; df = $48(\mathrm{p}<0.0001), \mathrm{I}^{2}=$ 81.9\%), negative LR (Cochrane- $\mathrm{Q}=201.46$; $\mathrm{df}=48(\mathrm{p}$ $\left.<0.0001), \mathrm{I}^{2}=76.2 \%\right)$, and diagnostic odds ratio (Cochrane- $\mathrm{Q}=143.88 ; \mathrm{df}=48(\mathrm{p}<0.0001), \mathrm{I}^{2}=$ $66.6 \%)$, thus suggesting other sources of heterogeneity across the studies. Accordingly, meta-regression analysis with the following covariates was performed: 1) type of tissue used for MSP, as paraffin embedded specimens may not yield enough quality DNA to successfully perform the test [86]; 2) anti-MGMT antibody used, as the best agreement between MSP and IHC results seems to be achieved when using the MT23.2 antibody [33]; and 3 ) type of tumour analyzed. Results suggest that the 
type of tumour is strongly associated with accuracy (RDOR 5.36; 95\% CI[2.42-11.86], p < 0.01) (Additional file 7).

In the next step, a second meta-regression analysis was performed for the subgroup of 36 studies in which semiquantitative scoring for IHC was used, and the cut-off value was also included as covariate. Interestingly, the type of tumour (primary brain tumour vs. others) was also selected as an independent covariate of accuracy estimates beyond cut-off value, type of tissue or type of antibody used. MGMT protein expression by IHC for brain tumours is associated with a more than four-fold lower accuracy compared to other tumours (RDOR 4.38; 95\% CI[1.82-10.54], $\mathrm{p}=0.0017$ ) (Additional file 8).

The final step of the analysis was pooling accuracy estimates in homogeneous subgroups of studies with identical type of tumour and identical cut-off value. To rule out an implicit threshold effect due to naturally occurring variations in the interpretation between observers, laboratories or devices, the Spearman rank correlation was performed, and no evidence of threshold effect within these groups was found. Overall, the summary estimates found ranged from $0.53 ; 95 \% \mathrm{CI}[0.33-0.73]$ to 0.79 ; $95 \% \mathrm{CI}[0.73-0.84]$ for sensitivity and from 0.60 ; $95 \% \mathrm{CI}[0.52-0.67]$ to 0.93 ; $95 \% \mathrm{CI}[0.91-0.95]$ for specificity (Additional file 9).

To further evaluate diagnostic accuracy for MGMT protein expression by IHC when identical scoring and cut-off values were used, we determined the $\mathrm{Q}^{*}$ index. Figures $4 \mathrm{~A}$ and $4 \mathrm{~B}$ show that the $\mathrm{Q}^{*}$ index was 0.64 and the area under the curve (AUC) 0.68 for brain tumour studies, while the Q*index was 0.80 and the AUC 0.87 for non-brain tumour series, indicating a statistically significant higher level of overall accuracy in systemic tumours (z-statistic 4.354, $\mathrm{p}<0.0001$ ). This difference remained statistically significant when we included all studies in the analysis (z-statistic 5.722, p < 0.0001).

Finally, the Egger's regression test for the detection of publication bias showed an asymmetrical distribution of the points in the funnel-plot (Intercept 1.55; 95\% CI [0.61-2.49], $\mathrm{p}=0.002$ ) (Figure 5), indicating a potential publication bias.

\section{Discussion}

The relevance of MGMT status as a potential prognostic or predictive factor in malignant glioma patients is supported by a number of independent studies. At present, detection of MGMT promoter methylation by MSP is the most commonly used method and for this reason it is considered the reference test in the present review. However, concerning day-to-day clinical practice, MSP is not yet part of the routine diagnostic work-up while MGMT assessment at RNA or protein-level are used $[22,33]$. The exact incidence of promoter methylation, protein or RNA expression varies according to the assessment test and among different studies [87]. An optimal method for diagnostic purposes should be widely available, easy to establish, cost-effective, reproducible both within a given laboratory and among different laboratories, and capable of yielding results that show consistent association with patient outcome $[19,33]$. In this regard MSP is a highly sensitive qualitative technique, but IHC has several advantages over it [88].

Although strong agreement between MSP and IHC has been previously reported, there is growing evidence that MGMT promoter methylation assessment through MSP does not correlate well with MGMT protein expression as detected by IHC in brain tumours $[25,26,31,68,89]$. In addition, some studies have shown that MGMT promoter methylation and MGMT protein expression cannot be used interchangeably to predict patient survival or glioma chemosensitivity $[68,90]$. Results from the present meta-analysis support this evidence and suggest that cases selected by IHC may not always correspond to those selected by MSP. In fact, diagnostic accuracy estimates for MGMT protein expression by IHC were significantly lower for brain tumours than for other non-brain tumours (sensitivity, 53-64\% vs. $60-81 \%$ respectively; specificity, $60-84 \%$ vs. $80-93 \%$ respectively). Similarly, positive and negative likelihood ratios did not provide convincing diagnostic accuracy for IHC in brain tumours (Additional file 9). Accordingly, the type of tumour (primary brain $v s$. nonbrain systemic tumour) turned out to be an independent covariate of accuracy estimates in the meta-regression analysis beyond other methodological covariates such as cut-off value and type of antibody.

The reasons for these findings are not clear and different putative causes must be taken into consideration. First, there is a lack of a consistently defined cut-off value for the semiquantitative immunohistochemical scoring. Capper et al. proposed a cut-off of $15 \%$ immunolabeled cells for GBM and 35\% for low grade gliomas [22], Nakasu et al. proposed a cut-off value of 10-20\% [88], and Preusser et al. found the best agreement between MSP and IHC results when using a cut-off of $50 \%$ [20]. It is important to note that the cut-off value was not an independent covariate of accuracy in the present meta-regression analysis, whereas the type of tumour (primary brain vs non-brain) was independently associated with greater accuracy (Additional files 7 and 8). In addition, interobserver variability in discriminating positive and negative cells, specific immunostaining and background is another technical aspect of the IHC procedure [20]. Even when studies use the same explicit threshold, their implicit threshold may differ, especially if interpretation of the test requires pathology 
A.

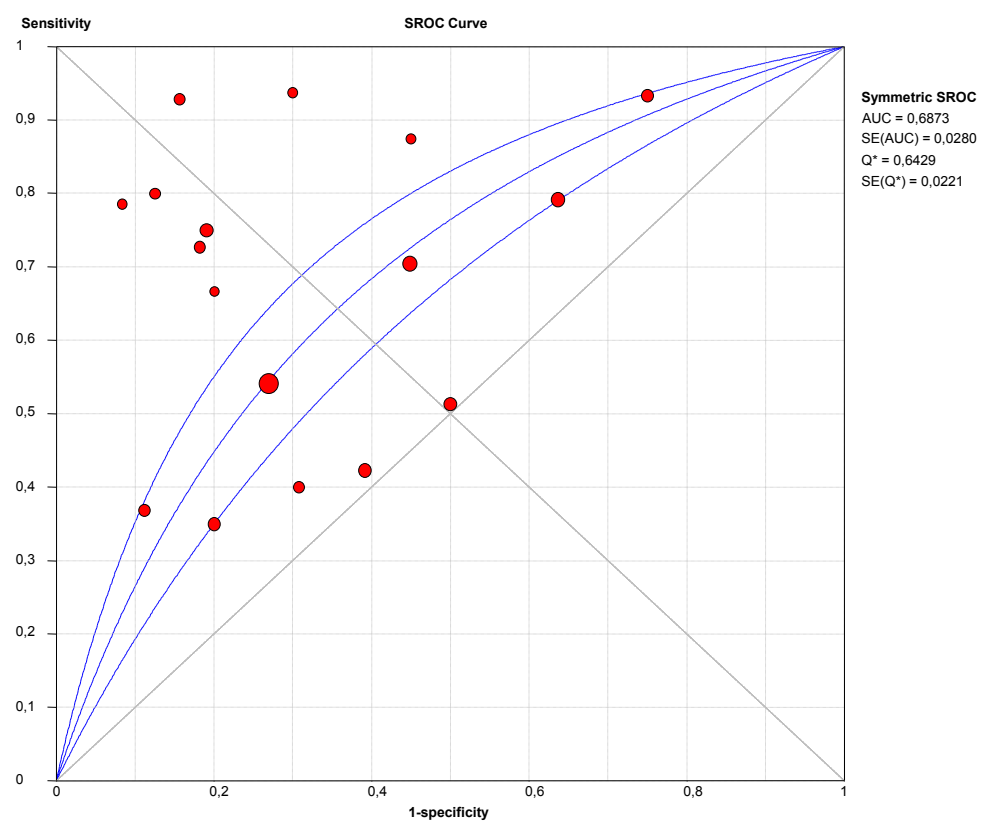

B.

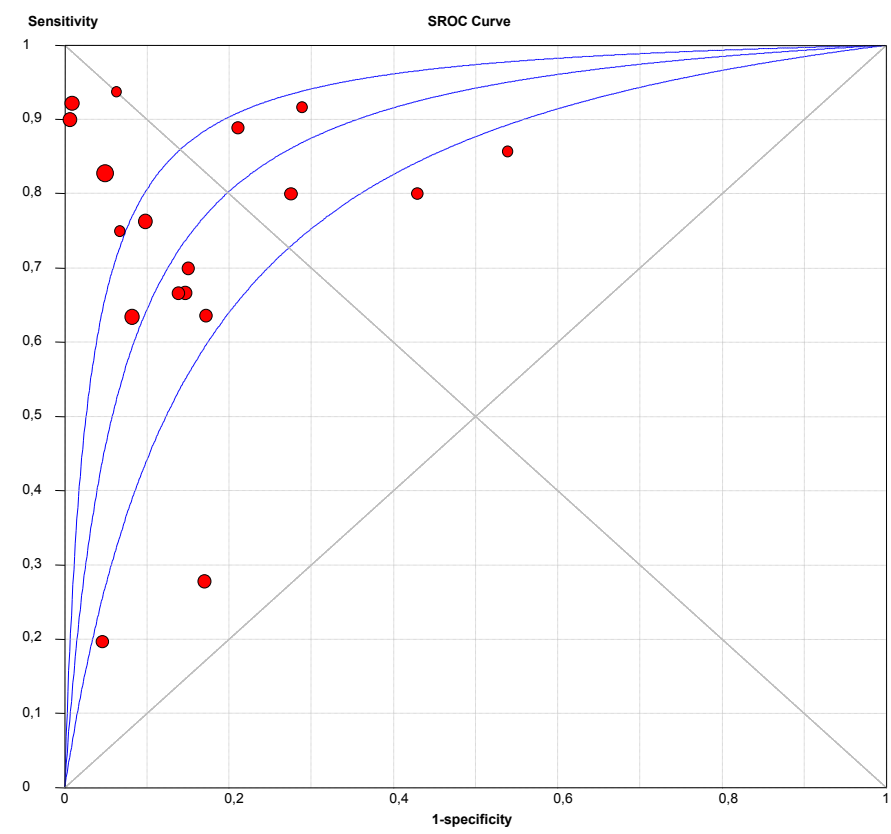

Figure 4 SROC curves for studies with IHC semiquantitative scoring. (A) SROC curve for brain tumour studies with $I H C$ semiquantitative scoring. (B) SROC curve for non-brain tumour studies with $\mathrm{HC}$ semiquantitative scoring.

judgement [35]. Importantly, histological analysis of the tissue used for DNA extraction is not always performed (Additional file 3 and Additional file 4), and when the area of tumour used for MSP analysis is different from the one studied with IHC, necrosis and/or an overlarge sample of normal tissue might hamper the MSP results. Third, due to the fact that MSP relies on the different susceptibility of methylated versus unmethylated cytosines to sodium bisulfite modification and subsequent selective primers amplification, it is highly dependent on tissue quality and quantity, primer design, bisulfite treatment adequacy and PCR conditions [19]. Finally, MSP is so highly sensitive that a methylation band may be obtained even if cells that carry MGMT promoter 


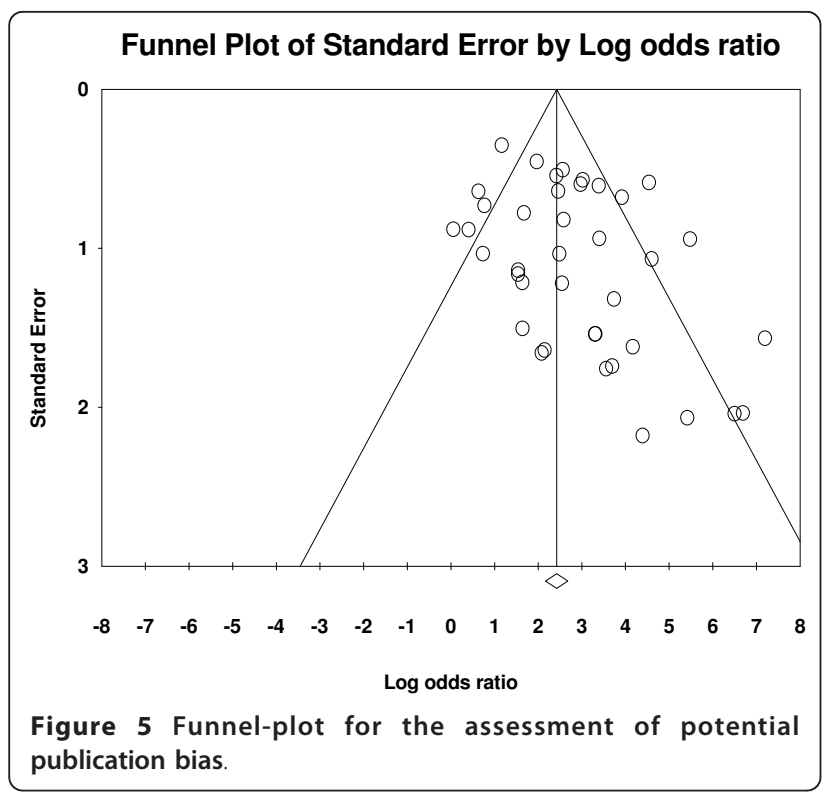

methylation represent a small proportion among the majority of cells with unmethylated promoter [1]. Conversely, IHC may not be able to detect small clusters of cells that have lost protein expression [91].

Apart from these technical issues, there are other confounding factors that may lead to false positive methylation results. Although it has been stated that the presence of a methylated MGMT allele can only be attributed to neoplastic cells $[8,10,92]$, some authors have demonstrated that $M G M T$ promoter methylation may occur in non-neoplastic central nervous system tissue [3] or in normal-appearing mucosa several centimetres away from digestive tumours [56,93]. Moreover, Candiloro et al. [94] have shown low levels of methylation in peripheral blood of healthy individuals with the $\mathrm{T}$ allele of the rs16906252 polymorphism.

Moreover, regulation of MGMT expression in brain tumours seems to be a complex phenomenon in which abnormal methylation of the promoter region may not be the only determining factor $[1,47,95-97]$. Similar to genetic and chromosomal events, epigenetic changes may also be tissue- and tumour-specific $[98,99]$. In fact, the inconsistency between promoter methylation and protein expression assessed by IHC in gliomas is not limited to the MGMT gene, but has also been observed for other genes such as PTEN [100]. Gliomas are heterogeneous tumours and intratumoural heterogeneity of MGMT staining and methylation is a well-known event. Over time, variations in the methylation status of MGMT promoter within the same tumour have also been described, although the relevance of these events is unclear $[31,89,101]$. Interestingly, some factors, such as glucocorticoids, ionizing radiation and chemotherapy, can induce MGMT expression [26,102]. Thus, a further question to be addressed is whether tumour recurrences exhibit the MGMT status as the pre-treatment tumour or a different one. Unfortunately, data on this topic are limited and contradictory [103]. While some studies have demonstrated an increase in MGMT immunostaining [84] or a lower frequency of $M G M T$ promoter methylation $[87,104,105]$ in recurrent gliomas after chemotherapy, other authors have not observed any change $[84,103,106]$. Finally, both an increase and a decrease in MGMT expression have also been described for recurrent tumours [22,76,87,107-109]. A higher protein expression might indicate that the MGMT gene has been up-regulated by the treatment, although other possible explanations, such as selection of chemoresistant cells with high MGMT protein levels or intratumoral regional variations, can not be excluded $[26,84,109]$.

Finally, methylation is not biallelic in some tumours, leaving one allele actively expressing the protein while MGMT promoter methylation may be also observed [110]. In fact, MGMT gene is located on chromosome $10 q$, a region lost in the vast majority of GBM, implying that even in those GBM without promoter methylation, MGMT haploinsufficiency is likely [101]. Moreover, MGMT promoter CpG islands may present a differential pattern of methylation along the region, with some CpGs being more important than others with regard to gene transcription. In this sense, it has been suggested that the region commonly investigated by MSP might not to be among those that best correlate with protein expression [90].

In an attempt to avoid some of the above mentioned problems, quantitative or semiquantitative methods such as MethylLight ${ }^{\circledR}$ quantitative MPS, pyrosequencing, COBRA, etc. $[66,67,70,83,87,89,111]$ have been reported by different groups in recent years. Whether these methods are more appropriate than MSP remains to be demonstrated in large cohorts of patients. Quantitative methods seem to provide better discrimination than classical gel-based MSP. However, as Karayan-Tapon et al. [46] note, before these methods can be used as clinical biomarkers, validation of them is required. Whichever gene is used for normalization, no quantitative-MSP assay can give a real, absolute measurement, and this might be a restriction. Moreover, completely quantitative or semiquantitative assays that normalize to a control gene or the copy number of the unmethylated $M G M T$ promoter sequence might underestimate MGMT methylation, because contaminating nontumoral tissue will contribute to the signal of the normalizing gene [112].

Both MGMT status at protein level and promoter methylation have been correlated with prognosis and chemosensitivity in glioma patients. As is shown in Additional file 3 and Additional file 4, the prognostic and predictive value of protein expression has been evaluated 
in some studies with contradictory results. Several authors have reported a significant association of MGMT expression assessed by immunohistochemistry with patients' overall or progression-free survival [22,23,31,88,113-117]. Some of them have even shown MGMT protein expression to be an independent predictor in the multivariate analysis $[31,84,85,115,116,118,119]$, whilst others have demonstrated a lack of correlation $[29,46,58,74]$. However, most published data were obtained from heterogeneous groups of patients with different grades and histologies, as well as distinct treatment protocols [31]. Although differences in study design could explain, at least in part, these contradictory results, other possibilities should be considered. In this sense, while those neoplastic cells that do not express MGMT may not be able to correct DNA damage induced by chemotherapy, loss of MGMT expression can also be a negative prognostic factor because of an increased susceptibility to acquiring other mutations [120-122]. Furthermore, due to variable interobserver agreement, insufficient correlation with MGMT promoter methylation status and the lack of a firm association with patient outcome $[20,29,103]$, MGMT IHC has not proved to be a clinically usable biomarker for routine diagnostic purposes and clinical decision-making.

Our review has several limitations. First, we excluded 17 studies because they did not provide data allowing construction of two-by-two tables, potentially resulting in less precise estimates of pooled diagnostic accuracy. Second, the statistical power of this meta-analysis was limited by the relatively small sample size of most included studies. Third, the QUADAS tool revealed that in approximately two-thirds of the studies partial verification bias was not clearly avoided, as not all cases evaluated with the index test went on to receive verification using the reference test. Another important aspect of study quality is the blinding of results of experimental and reference tests [123]. Unfortunately, in $84 \%$ of the studies, assessment of the reference test blinded for the IHC results was not explicitly stated by the authors, and in $73 \%$ of them no details were reported about blinding of the index test. Finally, publication bias was found in the present meta-analysis. Exclusion of non-English-language studies could contribute to explaining this fact, although a preference for publishing studies reporting positive results is a more plausible explanation [44].

\section{Conclusions}

The present systematic review and meta-analysis has shown that assessment of MGMT protein expression by IHC is not in good concordance with results obtained with the MSP test. Discordance between the two tests seems to be higher for brain tumours even when comparing subgroups with identical cut-off value. Therefore, it seems that MGMT promoter methylation does not always reflect gene expression and, accordingly, the two methods cannot be used interchangeably. We conclude that protein expression assessed by IHC alone fails to reflect the promoter methylation status of $M G M T$, and thus in clinical diagnostic attempts the two methods will not select the same group of patients. This fact can be of crucial importance when stratifying patients in clinical studies according to their MGMT status.

Despite all the above mentioned aspects, MSP currently remains the most established method and the best approach to assessing MGMT status. It is also the technique for which the most convincing clinical correlations have been reported and, thus, it should be considered the reference test. Unfortunately, it is a relatively complex and time-consuming method not apt for routine clinical implementation in many centres [19].

However, the analytical and clinical performance of MGMT immunoassaying seems to be inappropriate for routine diagnostic purposes. This fact, along with the lack of a robust association with MGMT promoter methylation as demonstrated in the present meta-analysis, precludes its use as a valuable biomarker for clinical decision making. It remains to be determined whether novel anti-MGMT antibodies directed against other epitopes would improve its performance [20].

Accordingly, some authors have suggested the feasibility of using MSP combined with IHC for prognostic and predictive purposes $[104,116]$. Immunohistochemistry may represent a useful preliminary test to identify methylated cases while MSP should be performed in non-immunoreactive cases to identify truly methylated tumours [70]. Again, this issue deserves further investigation.

\section{Additional material}

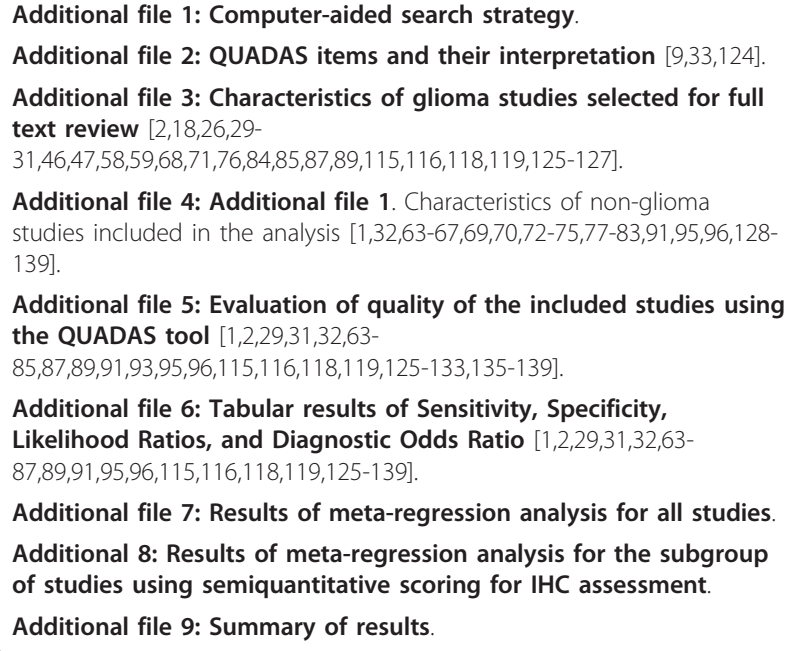

Additional file 5: Evaluation of quality of the included studies using the QUADAS tool $[1,2,29,31,32,63-$

$85,87,89,91,93,95,96,115,116,118,119,125-133,135-139]$.

Additional file 6: Tabular results of Sensitivity, Specificity, Likelihood Ratios, and Diagnostic Odds Ratio [1,2,29,31,32,63$87,89,91,95,96,115,116,118,119,125-139]$.

Additional file 7: Results of meta-regression analysis for all studies Additional 8: Results of meta-regression analysis for the subgroup of studies using semiquantitative scoring for IHC assessment. Additional file 9: Summary of results. 


\section{Ackowledgments}

We thank G. Frontera of the Investigation Unit, Son Dureta University Hospital, Palma de Mallorca, Spain, for statistical advice, and Tom Yohannan for language assistance.

This study was supported by grants from the Ministerio de Sanidad y Consumo (Fondo de Investigación Sanitaria 08/1085; Instituto de Salud Carlos III-RETIC RD06/0020/0097) and the Fundación Médica Mútua Madrileña, 2007.

\section{Author details}

'Department of Neurosurgery, Son Dureta University Hospital, Palma de Mallorca, Spain. ${ }^{2}$ Department of Basic Nursing, IDIBELL-Universitat de Barcelona, L'Hospitalet de Llobregat, Spain.

\section{Authors' contributions}

All authors have participated sufficiently in the work to take public responsibility for appropriate portions of the content. MB and Jl have made the design, review of the literature, and acquisition and analysis of data. They have also contributed to manuscript drafting and have approved its final version. AT has been involved in the interpretation of data, manuscript writing and critical revision, and has also approved the final version.

\section{Competing interests}

The authors declare that they have no competing interests.

Received: 12 September 2010 Accepted: 26 January 2011

Published: 26 January 2011

\section{References}

1. Bae SI, Lee HS, Kim SH, Kim WH: Inactivation of O6-methylguanine-DNA methyltransferase by promoter $\mathrm{CpG}$ island hypermethylation in gastric cancers. Br J Cancer 2002, 86:1888-1892.

2. Esteller M, Hamilton SR, Burger PC, Baylin SB, Herman JG: Inactivation of the DNA repair gene $\mathrm{O}^{6}$-methylguanine-DNA methyltransferase by promoter hypermethylation is a common event in primary human neoplasia. Cancer Res 1999, 59:793-797.

3. Jaeckle KA, Eyre HJ, Townsend JJ, Schulman S, Knudson HM, Belanich M, Yarosh DB, Bearman SI, Giroux DJ, Schold SC: Correlation of tumor $0^{6}$ methylguanine-DNA methyltransferase levels with survival of malignant astrocytoma patients treated with bis-chloroethylnitrosourea: a Southwest Oncology Group study. J Clin Oncol 1998, 16:3310-3315.

4. Gerson SL: Clinical relevance of MGMT in the treatment of cancer. J Clin Oncol 2002, 20:2388-2399.

5. Jones PA, Laird PW: Cancer epigenetics comes from age. Nat Genet 1999, 21:163-167.

6. Robertson KD, Jones PA: DNA methylation: past, present and furture directions. Carcinogenesis 2000, 21:461-467.

7. Baylin SB, Herman JG: DNA hypermethylation in tumorigenesis: epigenetic joins genetics. Trends Genet 2000, 16:168-173.

8. Esteller M, García-Foncillas J, Andion E, Goodman SN, Hidalgo OF, Vanaclocha V, Baylin SB, Herman JG: Inactivation of the DNA-repair gene MGMT and the clinical response of gliomas to alkylating agents. N Eng J Med 2000, 343:1350-1354.

9. Hegi ME, Diserens AC, Gorlia T, Hamou MF, de Tribolet N, Weller M, Kros JM, Hainfellner JA, Mason W, Mariani L, Bromberg JEC, Hau P, Mirimanoff RO, Cairncross JG, Janzer RC, Stupp R: MGMT gene silencing and benefit from Temozolamide in glioblastoma. N Engl J Med 2005, 352:997-1003.

10. Hegi ME, Diserens AC, Godard S, Dietrich PY, Regli L, Ostermann S, Otten P, Van Melle G, de Tribolet N, Strupp R: Clinical trial substantiates the predictive value of O6-Metylguanine-DNA methyltransferase promoter methylation in glioblastoma patients treated with Temozolamide. Clin Cancer Res 2004, 10:1871-1874.

11. Crinière E, Kaloshi G, Laigle-Donadey F, Lejeune J, Auger N, BenouaichAmiel A, Everhard S, Mokhtari K, Polivka M, Delattre JY, Hoang-Xuan K, Thillet J, Sanson M: MGMT prognostic impact on glioblastoma is dependent on therapeutic modalities. J Neurooncol 2007, 83:173-179.

12. Everhard S, Kaloshi G, Crinière E, Benouaich-Amiel A, Lejeune J, Marie $Y$, Sanson M, Kujas M, Mokhtari K, Hoang-Xuan K, Delattre JY, Thillet J: MGMT Methylation: a marker of response to Temozolamide in low-grade gliomas. Ann Neurol 2006, 60:740-743.
13. Kamiryo T, Tada K, Shiraishi S, Shinojima N, Kochi M, Ushio Y: Correlation between promoter hypermethylation of the 06-methylguaninedeoxyribonucleic acid methyltransferase gene and prognosis in patients with high-grade astrocytic tumors treated with surgery, radiotherapy, and 1-(4-amino-2-methyl-5-pyrimidinyl)methyl-3-(2chloroethyl)-3-nitrosourea-based chemotherapy. Neurosurgery 2004, 52:349-357.

14. Watanabe T, Katayama Y, Komine C, Yoshino A, Ogino A, Ohta T, Fukushima T: O6-Methylguanine-DNA methyltransferase methylation and TP53 mutation in malignant astrocytomas and their relationships with clinical course. Int I Cancer 2005, 113:581-587.

15. Gorlia T, van den Bent MJ, Hegi ME, Mirimanoff RO, Weller M, Cairncross JG, Eisenhauer E, Belanger K, Brandes AA, Allgeier A, Lacombe D, Stupp R: Nomograms for predicting survival of patients with newly diagnosed glioblastoma: prognostic factor analysis of EORTC and NCIC trial 2698122981/CE.3. Lancet Oncol 2008, 9:29-38.

16. Sadones J, Michotte A, Veld P, Chaskis C, Sciot R, Menten J, Joossens EJ, Strauven T, D'Hondt LA, Sartenaer D, Califice SF, Bierau K, Svensson C, De Greve J, Neyns B: MGMT promoter hypermethylation correlates with a survival benefit from temozolomide in patients with recurrent anaplastic astrocytoma but not glioblastoma. Eur J Cancer 2009, 45:146-153.

17. Shaw RJ, Hall GL, Lowe D, Liloglou T, Field JK, Sloan P, Risk JM: The role of pyrosequencing in head and neck cancer epigenetics: correlation of quantitative methylation data with gene expression. Arch Otolaryngol Head Neck Surg 2008, 134:251-256.

18. Preusser M, Elezi L, Hainfellner JA: Reliability and reproducibility of PCRbased testing of O6-methylguanine-DNA methyltransferase gene (MGMT) promoter methylation status in formalin-fixed and paraffinembedded neurosurgical biopsy specimens. Clin Neuropathol 2008, 27:388-390.

19. Yip S, lafrate AJ, Louis DN: Molecular diagnostic testing in malignant gliomas: a practical update on predictive markers. J Neuropathol Exp Neurol 2008, 67:1-15.

20. Preusser M, Charles JR, Felsberg J, Reifenberger G, Hamou MF, Diserens AC, Stupp R, Gorlia T, Marosi C, Heinzl H, Hainfellner JA, Hegi M: Anti-O6methylguanine-methyltransferase (MGMT) immunohistochemistry in glioblastoma multiforme: observer variability and lack of association with patient survival impede its use as clinical biomarker. Brain Pathol 2008, 18:520-532.

21. Andersson U, Malmer B, Bergenheim AT, Brännström T, Henriksson R: Heterogeneity in the expression of markers for drug resistance in brain tumors. Clin Neuropathol 2004, 23:21-27.

22. Capper D, Mittelbronn M, Meyermann R, Schittenhelm J: Pitfalls in the assessment of MGMT expression and its correlation with survival in diffuse astrocytomas: proposal of feasible immunohistochemical approach. Acta Neuropathol 2008, 115:249-259.

23. Chinot OL, Barrie M, Fuentes $S$, Eudes $N$, Lancelot $S$, Metellus $P$, Muracciole X, Braguer D, Ouafik L, Martin PM, Dufour H, Figarella-Branger D: Correlation between O6-methylguanine-DNA methyltransferase and survival in inoperable newly diagnosed glioblastoma patients treated with neoadjuvant temozolomide. J Clin Oncol 2007, 25:1470-1475.

24. Friedman HS, McLendon RE, Kerby T, Dugan M, Bigner SH, Henry AJ, Ashley DM, Krischer J, Lovell S, Rasheed K, Marchev F, Seman AJ, Cokgor I, Rich J, Stewart E, Colvin OM, Provenzale JM, Bigner DD, Haglund MM, Friedman AH, Modrich PL: DNA Mismatch repair and O6-alkyguanineDNA alkyltransferase analysis and response to Temodal in newly diagnosed malignant glioma. J Clin Oncol 1998, 16:3851-3857.

25. Idbaih A, Omuro A, Ducray F, Hoang-Xuan K: Molecular genetic markers as predictors of response to chemotherapy in gliomas. Curr Opin Oncol 2007, 19:606-611.

26. Jeuken JW, Cornelissen SJ, Vriezen M, Dekkers MM, Errami A, Sijben A, Boots-Sprenger SH, Wesseling P: MS-MLPA: an attractive alternative laboratory assay for robust, reliable, and semiquantitative detection of MGMT promoter hypermethylation in gliomas. Lab Invest 2007, 87:1055-1065.

27. McLendon RE, Cleveland L, Pegram C, Bigner SH, Bigner DD, Friedman HS: Immunohistochemical detection of the DNA repair enzyme O6methylguanine-DNA methyltransferase in formalin-fixed, paraffinembedded astrocytomas. Lab Invest 1998, 78:643-644.

28. Pollack IF, Hamilton RL, Sobol RW, Burnham J, Yates AJ, Holmes EJ, Zhou T, Finlay JL: O6-methylguanine-DNA methyltransferase expression strongly 
correlates with outcome in childhood malignant gliomas: results from the CCG-945 Cohort. J Clin Oncol 2006, 24:3431-3437.

29. Rodriguez FJ, Thibodeau SN, Jenkins RB, Schowalter KV, Caron BL, O'Neil BP, James CD, Passe S, Slezak J, Giannini C: MGMT Immunohistochemical expression and promoter methylation in human glioblastoma. App/ Immunohistochem Mol Morphol 2008, 16:59-65.

30. Yachi K, Watanabe T, Ohta T, Fukushima T, Yoshino A, Ogino A, Katayama Y, Nagase H: Relevance of MSP assay for the detection of MGMT promoter hypermethylation in glioblastomas. Int I Oncol 2008, 33:469-475.

31. Brell M, Tortosa A, Verger E, Gil JM, Viñolas N, Villà S, Acebes JJ, Caral Pons JJ, Pujol T, Ferrer I, Ribalta T, Graus F: Prognostic significance of O6 Methilguanine DNA methyltransferase determined by promoter methylation and immunohistochemical expression in anaplastic gliomas. Clin Cancer Res 2005, 11:5167-5171.

32. Ingold B, Schraml P, Heppner FL, Moch H: Homogeneous MGMT immunoreactivity correlates with an unmethylated MGMT promoter status in brain metastases of various solid tumors. PLOS ONE 2009, 4: e4775.

33. Preusser M: MGMT analysis at DNA, RNA and protein levels in glioblastoma tissue. Histol Histopathol 2009, 24:511-518.

34. Leeflang MM, Deeks JJ, Gatsonis C, Bossuyt PM: Systematic reviews of diagnostic test accuracy. Ann Intern Med 2008, 149:889-897.

35. Irwig L, Tosteson AN, Gatsonis C, Lau J, Colditz G, Chalmers TC, Mosteller F: Guidelines for meta-analyses evaluating diagnostic tests. Ann Intern Med 1994, 120:667-676

36. Deville WL, Buntinx F, Bouter LM, Montori VM, de Vet HC, van der Windt DA, bezemer PD: Conducting systematic reviews of diagnostic studies: didactic guidelines. BMC Med Res Methodol 2002, 2:9.

37. Virgili G, Conti AA, Murro V, Gensini GF, Gusinu R: Systematic reviews of diagnostic test accuracy and the Cochrane collaboration. Intern Emerg Med 2009, 4:255-258.

38. Whiting P, Rutjes AW, Reitsma JB, Bossuyt PM, Kleijnen J: The development of QUADAS: a tool for the quality assessment of studies of diagnostic accuracy included in systematic reviews. BMC Med Res Methodol 2003, 3:25.

39. Berman NG, Parker RA: Meta-analysis: neither quick nor easy. BMC Med Res Methodol 2002, 2:10.

40. Bossuyt PM, Reitsma JB, Bruns DE, Gatsonis CA, Glasziou PP, Irwig LM, Lijmer JG, Moher D, Rennie D, de Vet HC: Towards complete and accurate reporting of studies of diagnostic accuracy: The STARD Initiative. Ann Intern Med 2003, 138:40-44.

41. Glas AS, Lijmer JG, Prins MH, Bonsel GJ, Bossuyt PM: The diagnostic odds ratio: a single indicator of test performance. J Clin Epidemiol 2003, 56:1129-1135.

42. Higgins JP, Thompson SG, Deeks JJ, Altman DG: Measuring inconsistency in meta-analyses. BMJ 2003, 327:557-560.

43. Sterne JA, Egger M: Funnel plots for detecting bias in meta-analysis: guidelines on choice of axis. J Clin Epidemiol 2001, 54:1046-1055.

44. Egger M, Smith GD, Schneider M, Minder C: Bias in meta-analysis detected by a simple, graphical test. BMJ 1997, 315:629-634.

45. Zamora J, Abraira V, Muriel A, Khan K, Coomarasamy A: Meta-DiSc: a software for meta-analysis of test accuracy data. BMC Med Res Methodol 2006, 6:31.

46. Karayan-Tapon L, Quillien V, Guilhot J, Wager M, Fromont G, Saikali S, Etcheverry A, Hamlat A, Loussouarn D, Campion L, Campone M, Vallette FM, Gratas-Rabbia C: Prognostic value of O(6)-methylguanine-DNA methyltransferase status in glioblastoma patients, assessed by five different methods. I Neurooncol 2010, 97:311-322.

47. Rood BR, Zhang H, Cogen PH: Intercellular heterogeneity of expression of the MGMT DNA repair gene in pediatric medulloblastoma. NeuroOncology 2004, 6:200-207.

48. Zhang D, Bai Y, Wang Y, Luo J, Ge Q, Qiao Y, Jia C, Lu Z: Detailed methylation patterns and protein expression profiles of MGMT in colorectal carcinoma surgical margins. Clin Biochem 2008, 41:19-25.

49. Voelter V, Diserens AC, Moulin A, Nagel G, Yan P, Migliavacca E, Rimoldi D, Hamou MF, Kaina B, Leyvraz S, Hegi ME: Infrequent promoter methylation of the MGMT gene in liver metastases from uveal melanoma. Int $J$ Cancer 2008, 123:1215-1218.

50. Martin P, Garcia-Cosio M, Santon A, Bellas C: Aberrant gene promoter methylation in plasma cell dyscrasias. Exp Mol Pathol 2008, 84:256-261.
51. Rietschel P, Wolchok JD, Krown S, Gerst S, Jungbluth AA, Busam K, Smith K, Orlow I, Panageas K, Chapman PB: Phase II study of extended-dose temozolomide in patients with melanoma. J Clin Oncol 2008, 26:2299-2304.

52. Lin Z, Gao M, Zhang X, Kim YS, Lee ES, Kim HK, Kim I: The hypermethylation and protein expression of p16 INK4A and DNA repair gene 06-methylguanine-DNA methyltransferase in various uterine cervical lesions. J Cancer Res Clin Oncol 2005, 131:364-370.

53. Furonaka O, Takeshima Y, Awaya H, Kushitani K, Kohno N, Inai K: Aberrant methylation and loss of expression of O6-Methylguanine-DNA methyltransferase in pulmonary squamous cell carcinoma and adenocarcinoma. Pathol Int 2005, 55:303-309.

54. Brock MV, Gou M, Akiyama Y, Muller A, Wu TT, Montgomery E, Deasel M, Germonpré P, Rubinson L, Heitmiller RH, Yang SC, Forastiere AA, Baylin SB, Herman JG: Prognostic importance of promoter hypermethylation of multiple genes in esophageal adenocarcinoma. Clin Cancer Res 2003, 9:2912-2919.

55. Nagasaka T, Sharp GB, Notohara K, Kambara T, Sasamoto H, Isozaki H, MacPhee DG, Jass JR, Tanaka N, Matsubara N: Hypermethylation of O6Methylguanine-DNA methyltransefarse promoter may predict nonrecurrence after chemotherapy in colorectal cancer cases. Clin Cancer Res 2003, 9:5306-5312.

56. Zhang L, Lu W, Miao X, Xing D, Tan W, Lin D: Inactivation of DNA repair gene O6-Methylguanine-DNA methyltransferase by promoter hypermethylation and its relation to $p 53$ mutations in esophageal squamous cell carcinoma. Carcinogenesis 2003, 24:1039-1044.

57. Matsukura S, Soejima H, Nakagawachi T, Yakushiji H, Ogawa A, Fukuhara M, Miyazaki K, Nakabeppu Y, Sekiguchi M, Mukai T: CpG methylation of MGMT and hMLH1 promoter in hepatocellular carcinoma associated with hepatitis viral infection. Br J Cancer 2003, 88:521-529.

58. Mellai M, Caldera V, Annovazzi L, Chio A, Lanotte M, Cassoni P, Finocchiaro G, Schiffer D: MGMT promoter hypermethylation in a series of 104 glioblastomas. Cancer Genomics Proteomics 2009, 6:219-227.

59. Yang SH, Kim YH, Kim JW, Park CK, Park SH, Jung HW: Methylation status of the O6-Methylguanine-deoxyribonucleic acid methyltransferase gene promoter in World Health Organization grade III gliomas. J Korean Neurosurg Soc 2009, 46:385-388.

60. Herfarth KK, Brent TP, Danam RP, Remack JS, Kodner IJ, Wells SA, Goodfellow PJ: A specific CpG methylation pattern of the MGMT promoter region associated with reduced MGMT expression in primary colorectal cancers. Mol Carcinog 1999, 24:90-98.

61. Yin D, Xie D, Hofmann WK, Zhang W, Asotra K, Wong R, Black KL, Koeffler HP: DNA repair gene O6-methylguanine-DNA methyltransferase: promoter hypermethylation associated with decreased expression and G:C to A:T mutations of p53 in brain tumors. Mol Carcinog 2003, 36:23-31.

62. Lazcoz P, Munoz J, Nistal M, Pestana A, Encio IJ, Castresana JS: Loss of heterozygosity and microsatellite instability on chromosome arm 10q in neuroblastoma. Cancer Genet Cytogenet 2007, 174:1-8.

63. Qi J, Zhu YQ, Huang MF, Yang D: Hypermethylation of CpG island in O6methylguanine-DNA methyltransferase gene was associated with K-ras $G$ to A mutation in colorectal tumor. World I Gastroenterol 2005, 11:2022-2025.

64. Rimel BJ, Huettner P, Powell MA, Mutch DG, Goodfellow PJ: Absence of MGMT promoter methylation in endometrial cancer. Gynecol Oncol 2009, 112:224-228.

65. McCormack Al, McDonald KL, Gill AJ, Clark SJ, Burt MG, Campbell KA, Braund WJ, Little NS, Cook RJ, Grossman AB, Robinson BG, Clifton-Bligh RJ: Low O(6)-methylguanine-DNA methyltransferase (MGMT) expression and response to temozolomide in aggressive pituitary tumours. Clin Endocrinol (Oxf) 2009, 71:226-233.

66. Nagasaka T, Goel A, Notohara K, Takahata T, Sasamoto H, Uchida T, Nishida N, Tanaka N, Boland CR, Matsubara N: Methylation pattern of the O6-methylguanine-DNA methyltransferase gene in colon during progressive colorectal tumorigenesis. Int J Cancer 2008, 122:2429-2436.

67. Baumann S, Keller G, Puhringer F, Napieralski R, Feith M, Langer R, Hofler $H$, Stein HJ, Sarbia M: The prognostic impact of O6-Methylguanine-DNA Methyltransferase (MGMT) promotor hypermethylation in esophageal adenocarcinoma. Int J Cancer 2006, 119:264-268.

68. Maxwell JA, Johnson SP, Quinn A, McLendon RE, Ali-Osman F, Friedman AH, Herndon JE II, Bierau K, Bigley J, Bigner DD, Friedman HS: 
Quantitative analysis of O6-alkylguanine-DNA alkyltransefarse in malignant glioma. Mol Cancer Ther 2006, 5:2531-2539.

69. Chu LC, Eberhart CG, Grossman SA, Herman JG: Epigenetic silencing of multiple genes in primary CNS lymphoma. Int I Cancer 2006, 119:2487-2491.

70. Uccella S, Cerutti R, Placidi C, Marchet S, Carnevali I, Bernasconi B, Proserpio I, Pinotti G, Tibiletti MG, Furlan D, Capella C: MGMT methylation in diffuse large B-cell lymphoma: validation of quantitative methylationspecific PCR and comparison with MGMT protein expression. J Clin Pathol 2009, 62:715-723.

71. Möllemann M, Wolter M, Felsberg J, Collins VP, Reifenberger G: Frequent promoter hypermethylation and low expression of the MGMT gene in oligodendroglial tumors. Int J Cancer 2005, 113:379-385.

72. Munot K, Bell SM, Lane S, Horgan K, Hanby AM, Speirs V: Pattern of expression of genes linked to epigenetic silencing in human breast cancer. Hum Pathol 2006, 37:989-999.

73. Wolf P, Hu YC, Doffek K, Sidransky D, Ahrendt SA: O(6)- MethylguanineDNA methyltransferase promoter hypermethylation shifts the p53 mutational spectrum in non-small cell lung cancer. Cancer Res 2001, 61:8113-8117.

74. Lee GW, Kang JH, Kim IS, Kim HG, Ko GH, Lee JH, Kim DC, Song DH, Yang JW, Lee JS: Is inactivation of O(6)-methylguanine DNA methyltransferase still a favorable prognostic factor of patients with diffuse large B-cell lymphoma in the era of R-CHOP chemotherapy? Leuk Lymphoma 2009, 50:1992-1998.

75. Herath NI, Walsh MD, Kew M, Smith JL, Jass JR, Young J, Leggett BA, Macdonald GA: Silencing of O6-methylguanine DNA methyltransferase in the absence of promoter hypermethylation in hepatocellular carcinomas from Australia and South Africa. Oncol Rep 2007, 17:817-822.

76. Lavon I, Zrihan D, Zelikovitch B, Fellig Y, Fuchs D, Soffer D, Siegal T: Longitudinal assessment of genetic and epigenetic markers in oligodendrogliomas. Clin Cancer Res 2007, 13:1429-1437.

77. Martin P, Santon A, Garcia-Cosio M, Bellas C: hMLH1 and MGMT inactivation as a mechanism of tumorigenesis in monoclonal gammopathies. Mod Pathol 2006, 19:914-921.

78. Ogawa T, Yoshida T, Tsuruta T, Saigenji K, Okayasu I: Genetic instability on chromosome 17 in the epithelium of non-polypoid colorectal carcinomas compared to polypoid lesions. Cancer Sci 2006, 97:1335-1342.

79. Rossi D, Capello D, Gloghini A, Franceschetti S, Paulli M, Saglio G, Vitolo U, Pileri SA, Esteller M, Carbone A, Gaidano G: Aberrant promoter methylation of multiple genes throughout the clinico-pathologic spectrum of B-cell neoplasia. Haematologia 2004, 89:154-164.

80. Kim SH, Bae SI, Lee HS, Kim WH: Alteration of O6-methylguanie-DNA methyltransferase in colorectal neoplasms in sporadic and familial adenomatous polyposi patients. Mol Carcinog 2003, 37:32-38.

81. Choy KW, Pang CP, To KF, Yu C, Ng JSK, Lam DSC: Impaired expression and promotor hypermethylation of O6-Methylguanine-DNA Methyltransferase in retinoblastoma tissues. Invest Ophthalmol Vis Sci (PA) 2002, 43:1344-1349.

82. Whitehall VL, Walsh MD, Young J, Leggett BA, Jass JR: Methylation of O6methylguanine DNA methyltransferase characterizes a subset of colorectal cancer with low-level DNA microsatellite instability. Cancer Res 2001, 61:827-830.

83. Wu PF, Kuo KT, Kuo LT, Lin YT, Lee WC, Lu YS, Yang CH, Wu RM, Tu YK, Tasi JC, Tseng HM, Tseng SH, Cheng AL, Lin CH: O(6)- Methylguanine-DNA methyltransferase expression and prognostic value in brain metastases of lung cancers. Lung Cancer 2010, 68:484-490.

84. Metellus P, Coulibaly B, Nanni I, Fina F, Eudes N, Giorgi R, Barrie M, Chinot O, Fuentes S, Dufour H, Ouafik L, Figarella-Branger D: Prognostic impact of O6-methylguanine-DNA methyltransferase silencing in patients with recurrent glioblastoma multiforme who undergo surgery and carmustine wafer implantation: a prospective patient cohort. Cancer 2009, 115:4783-4794

85. Sonoda $Y$, Kumabe $T$, Watanabe M, Nakazato $Y$, Inoue T, Kanamori M, Tominaga T: Long-term survivors of glioblastoma: clinical features and molecular analysis. Acta Neurochir (Wien) 2009, 151:1349-1358.

86. Mikeska T, Bock C, El-Maarri O, Hubner A, Ehrentraut D, Schramm J, Felsberg J, Kahl P, Buttner R, Pietsch T, Waha A: Optimization of quantitative MGMT promoter methylation analysis using pyrosequencing and combined bisulfite restriction analysis. J Mol Diagn 2007, 9:368-381.
87. Parkinson JF, Wheeler HR, Clarkson A, Mckenkie CA, Biggs MT, Little NS, Cook RC, Messina M, Robinson BG, McDonald KL: Variation of O6Methylguanine-DNA Methyltransferase (MGMT) promoter methylation in serial samples of glioblastoma. J Neurooncol 2008, 87:71-78.

88. Nakasu S, Fukami T, Baba K, Matsuda M: Immunohistochemical study for O6-Methylguanine-DNA methyltransferase in the non-neoplastic and neoplastic components of gliomas. I Neurooncol 2004, 70:333-340.

89. Grasbon-Frodl EM, Kreth FW, Ruiter M, Schnell O, Bise K, Felsberg J, Reifenberg G, Tonn JC, Kretzschmar HA: Intratumoral homogeinity of MGMT promoter hypermetilation as demonstrated in serial stereotactic specimens for anaplastic astrocytomas and glioblastomas. Int I Cancer 2007, 121:2458-2464.

90. Everhard S, Tost J, El AH, Criniere E, Busato F, Marie Y, Gut IG, Sanson M, Mokhtari K, Laigle-Donadey F, Hoang-Xuan K, Delattre JY, Thillet J: Identification of regions correlating MGMT promoter methylation and gene expression in glioblastomas. Neuro Oncol 2009, 11:348-356.

91. Kohonen-Corish MR, Daniel JJ, Chan C, Lin BP, Kwun SY, Dent OF, Dhillon VS, Trent RJ, Chapuis PH, Bokey EL: Low microsatellite instability is associated with poor prognosis in stage C colon cancer. J Clin Oncol 2005, 23:2318-2324.

92. Stupp R: Methylguanine methyltransefrase testing in glioblastoma: when and how? J Clin Oncol 2007, 25:1459-1460.

93. Shen L, Kondo Y, Rosner GL, Xiao L, Supunpong Hernandez N, Vilaythong J, Houlihan PS, Krouse RS, Prasad AR, Einspahr JG, Buckmeier J, Alberts DS, Hamilton SR, Issa J-PJ: MGMT promoter methylation and field defect in sporadic colorectal cancer. J Natl Cancer Inst 2005, 97:1330-1338.

94. Candiloro IL, Dobrovic A: Detection of MGMT promoter methylation in normal individuals is strongly associated with the $T$ allele of the rs 16906252 MGMT promoter single nucleotide polymorphism. Cancer Prev Res (Phila) 2009, 2:862-867.

95. Park TJ, Han SU, Cho YK, Paik WK, Kim YB, Lim IK: Methylation of O6Methylguanine-DNA methyltransferase gene is associated significantly with K-ras mutation, lymph node invasion, tumor staging, and disease free survival in patients with gastric carcinoma. Cancer 2001, 92:2760-2768.

96. Smith-Sorensen B, Lind GE, Skotheim RI, Fossa SD, Fodstad O, Stenwig A-E Jakobsen KS, Lothe RA: Frequent promoter hypermethylation of the O6Methylguanine-DNA methyltransferase (MGMT) gene in testicular cancer. Oncogene 2002, 21:8878-8884

97. Bhakat KK, Mitra S: CpG methylation-dependent repression of the human O6-Methylguanine-DNA methyltransferase gene linked to chromatin structure alteration. Carcinogenesis 2003, 24:1337-1345.

98. Esteller M, Corn PG, Baylin SB, Herman JG: A gene hypermethylation profile of human cancer. Cancer Res 2001, 61:3225-3229.

99. Lorente A, Mueller W, Urdangarin E, Lazcoz P, Lass U, von Deimling A, Castresana JS: RASSF1A, BLU, NORE1A, PTEN and MGMT expression and promoter methylation in gliomas and glioma cell lines and evidence of deregulated expression of de novo DNMTs. Brain Pathol 2009, 19:279-292.

100. Baeza N, Weller M, Yonekawa Y, Kleihues P, Ohgaki H: PTEN methylation and expression in glioblastomas. Acta Neuropathol 2003, 106:479-485.

101. lafrate AJ, Louis DN: "MGMT for pt mgmt": is Methylguanine-DNA Methyltransferase testing ready for patient management? J Mol Diagn 2008, 10:308-310.

102. Fritz G, Tano K, Mitra S, Kaina B: Inducibility of the DNA repair gene encoding 06-methylguanine-DNA methyltransferase in mammalian cells by DNA-damaging treatments. Mol Cell Biol 1991, 11:4660-4668.

103. Cahill DP, Levine KK, Betensky RA, Codd PJ, Romany CA, Reavie LB, Batchelor TT, Futreal PA, Stratton MR, Curry WT, lafrate AJ, Louis DN: Loss of the mismatch repair protein MSH6 in human glioblastomas is associated with tumor progression during temozolomide treatment. Clin Cancer Res 2007, 13:2038-2045.

104. Christmann M, Nagel G, Horn S, Krahn U, Wiewrodt D, Sommer C, Kaina B: MGMT activity, promoter methylation and immunohistochemistry of pretreatment and recurrent malignant gliomas: a comparative study on astrocytoma and glioblastoma. Int J Cancer 2010, 127:2106-2118.

105. Eoli M, Menghi F, Bruzzone MG, De ST, Valletta L, Pollo B, Bissola L, Silvani A, Bianchessi D, D'Incerti L, Filippini G, Broggi G, Boiardi A, Finocchiaro G: Methylation of O6-methylguanine DNA methyltransferase and loss of heterozygosity on $19 q$ and/or $17 p$ are overlapping features of secondary glioblastomas with prolonged survival. Clin Cancer Res 2007, 13:2606-2613. 
106. Jung TY, Jung S, Moon KS, Kim IY, Kang SS, Kim YH, Park CS, Lee KH: Changes of the O6-methylguanine-DNA methyltransferase promoter methylation and MGMT protein expression after adjuvant treatment in glioblastoma. Oncol Rep 2010, 23:1269-1276.

107. Nagane M, Kobayashi K, Ohnishi A, Shimizu S, Shiokawa Y: Prognostic significance of 06-methylguanine-DNA methyltransferase protein expression in patients with recurrent glioblastoma treated with temozolomide. Jpn J Clin Oncol 2007, 37:897-906.

108. Wiewrodt D, Nagel G, Dreimuller N, Hundsberger T, Perneczky A, Kaina B: MGMT in primary and recurrent human glioblastomas after radiation and chemotherapy and comparison with p53 status and clinical outcome. Int J Cancer 2008, 122:1391-1399.

109. Brandes AA, Franceschi E, Tosoni A, Bartolini S, Bacci A, Agati R, Ghimenton C, Turazzi S, Talacchi A, Skrap M, Marucci G, Volpin L, Morandi L, Pizzolitto S, Gardiman M, Andreoli A, Calbucci F, Ermani M: O(6)methylguanine DNA-methyltransferase methylation status can change between first surgery for newly diagnosed glioblastoma and second surgery for recurrence: clinical implications. Neuro Oncol 2010, 12:283-288.

110. Parkinson JF, Wheeler HT, McDonald KL: Contribution of DNA repair mechanisms to determining chemotherapy response in high-grade glioma. J Clin Neurosci 2008, 15:1-8

111. Candiloro IL, Mikeska T, Hokland P, Dobrovic A: Rapid analysis of heterogeneously methylated DNA using digital methylation-sensitive high resolution melting: application to the CDKN2B (p15) gene. Epigenetics Chromatin 2008, 1:7

112. Weller M, Stupp R, Reifenberger G, Brandes AA, van den Bent MJ, Wick W, Hegi ME: MGMT promoter methylation in malignant gliomas: ready for personalized medicine? Nat Rev Neurol 2010, 6:39-51.

113. Anda T, Shabani HK, Tsunoda K, Tokunaga Y, Kaminogo M, Shitaba S, Hayashi T, Iseki M: Relationsip between expression of O6-methylguanineDNA methyltransferase, glutathione-S-transferase $\pi$ in glioblastoma and the survival of the patients treated with nimustine hydrochloride: An immunohistochemical analysis. Neurol Res 2003, 25:241-248.

114. Nakasu S, Fukami T, Jito J, Matsuda M: Prognostic significance of loss of O6-methylguanine-DNA methyltransferase expression in supratentorial diffuse low-grade astrocytoma. Surg Neurol 2007, 68:603-608.

115. Nakagawa T, Ido K, Sakuma T, Takeuchi H, Sato K, Kubota T: Prognostic significance of the immunohistochemical expression of O6methylguanine-DNA methyltransferase, P-glycoprotein, and multidrug resistance protein-1 in glioblastomas. Neuropathology 2009, 29:388.

116. Cao VT, Jung TY, Jung S, Jin SG, Moon KS, Kim IY, Kang SS, Park CS, Lee KH, Chae $\mathrm{HJ}$ : The correlation and prognostic significance of MGMT promoter methylation and MGMT protein in glioblastomas. Neurosurgery 2009, 65:866-875.

117. Sonoda Y, Yokosawa M, Saito R, Kanamori M, Yamashita Y, Kumabe T, Watanabe M, Tominaga T: O(6)-Methylguanine DNA methyltransferase determined by promoter hypermethylation and immunohistochemical expression is correlated with progression-free survival in patients with glioblastoma. Int J Clin Oncol 2010, 15:352-358.

118. Kuo LT, Kuo KT, Lee MJ, Wei CC, Scaravilli F, Tsai JC, Tseng HM, Kuo MF, Tu YK: Correlation among pathology, genetic and epigenetic profiles, and clinical outcome in oligodendroglial tumors. Int J Cancer 2009, 124:2872-2879.

119. Felsberg J, Rapp M, Loeser S, Fimmers R, Stummer W, Goeppert M, Steiger HJ, Friedensdorf B, Reifenberger G, Sabel MC: Prognostic significance of molecular markers and extent of resection in primary glioblastoma patients. Clin Cancer Res 2009, 15:6683-6693.

120. Gerson SL: MGMT: its role in cancer aetiology and cancer therapeutics. Nat Rev Cancer 2004, 4:296-307.

121. Esteller M, Herman JG: Generating mutations but providing chemosensitivity: the role of O6-Methylguanine DNA methyltransferase in human cancer. Oncogene 2004, 23:1-8.

122. Herman JG, Baylin SB: Gene silencing in cancer is association with promoter hypermethylation. N Engl J Med 2003, 349:2042-2054.

123. Deeks JJ: Systematic reviews in health care: Systematic reviews of evaluations of diagnostic and screening tests. BMJ 2001, 323:157-162.

124. Leeflang MM, Debets-Ossenkopp YJ, Visser CE, Scholten RJ, Hooft L, Bijlmer HA, Reitsma JB, Bossuyt PM, Vandenbroucke-Grauls CM: Galactomannan detection for invasive aspergillosis in immunocompromised patients. Cochrane Database Syst Rev 2008, CD007394.
125. Sasai K, Nodagashira M, Aoyanagi E, Wang L, Katoh M, Murata J, Ozaki Y, Ito T, Fujimoto S, Kaneko S, Nagashima K, Tanaka S: Careful exclusion of non-neoplastic brain components is required for an appropiate evaluation of 06-methylguanine-DAN methyltransferase status in glioma. Am J Surg Pathol 2008, 32:1220-1227.

126. Buccoliero AM, Castiglione F, Rossi Deglínnocenti D, Paglierani M, Maio V, Gheri CF, Garbini F, Moncini D, Taddei A, Sardi I, Sanzo M, Giordano F, Mussa F, Genitori L, Taddei GL: O6-Methylguanine-DNA-Methylytansefrase in recurring anaplastic ependymomas: PCR and immunohistochemistry. J Chemother 2008, 20:263-268.

127. Cankovic M, Mikkelsen T, Rosenblum ML, Zarbo RJ: A simplified laboratory validated assay for MGMT promoter hypermethylation analysis of glioma specimens from formalin-fixed paraffin-embedded tissue. Lab Invest 2007, 87:392-397.

128. Kim Jl, Suh JT, Choi KU, Kang HJ, Shin DH, Lee IS, Moon TY, Kim WT: Inactivation of O(6)-methylguanine-DNA methyltransferase in soft tissue sarcomas: association with K-ras mutations. Hum Pathol 2009, 40:934-941.

129. Zou XP, Zhang B, Zhang XQ, Chen M, Cao J, Liu WJ: Promoter hypermethylation of multiple genes in early gastric adenocarcinoma and precancerous lesions. Hum Pathol 2009, 40:1534-1542.

130. Kuester D, El-Rifai W, Peng D, Ruemmele P, Kroeckel I, Peters B, Moskaluk CA, Stolte M, Monkemuller K, Meyer F, Schulz HU, Hartmann A, Roessner A, Schneider-Stock R: Silencing of MGMT expression by promoter hypermethylation in the metaplasia-dysplasia-carcinoma sequence of Barrett's esophagus. Cancer Lett 2009, 275:117-126.

131. Mikami T, Yoshida T, Numata Y, Shiraishi H, Araki K, Guiot MC, Jass JR, Okayasu I: Low frequency of promoter methylation of O6-methylguanine DNA methyltransferase and $\mathrm{hMLH} 1$ in ulcerative colitis-associated tumors: comparison with sporadic colonic tumors. Am J Clin Pathol 2007, 127:366-373.

132. Kawaguchi K, Oda Y, Saito T, Yamamoto H, Takahira T, Kobayashi C, Tamiya S, Tateishi N, Iwamoto Y, Tsuneyoshi M: DNA hypermethylation status of multiple genes in soft tissue sarcomas. Mod Pathol 2006, 19:106-114.

133. Fox EJ, Leahy DT, Geraghty R, Mulcahy HE, Fennelly D, Hyland JM, O'Donoghue DP, Sheahan K: Mutually exclusive promoter hypermethylation patterns of hMLH1 and O6-methylguanine DNA methyltransferase in colorectal cancer. J Mol Diagn 2006, 8:68-75.

134. Shen L, Kondo Y, Rosner GL, Xiao L, Supunpong Hernandez N, Vilaythong J, Houlihan PS, Krouse RS, Prasad AR, Einspahr JG, Buckmeier J, Alberts DS, Hamilton SR, Issa J-PJ: MGMT promoter methylation and field defect in sporadic colorectal cancer. J Natl Cancer Inst 2005, 97:1330-1338.

135. Koga Y, Kitajima Y, Miyoshi A, Sato K, Kitahara K, Soejima H, Miyazaki L: Tumor progression through epigenetic gene silencing of $O(6)$ methylguanine-DNA methyltransferase in human biliary tract cancers. Ann Surg Oncol 2005, 12:354-363.

136. Kang GH, Lee S, Lee HJ, Hwang KS: Aberrant CpG island hypermethylation of multiple genes in prostate cancer and prostatic intraepithelial neoplasia. J Pathol 2004, 202:233-240.

137. Zhang YJ, Chen Y, Ahsan H, Lunn RM, Lee PH, Chen CJ, Santella RM: Inactivation of the DNA repair gene O6-methylguanine-DNA methyltransferase by promoter hypermethylation and its relationship to aflatoxin B1-DNA adducts and p53 mutation in hepatocellular carcinoma. Int J Cancer 2003, 103:440-444.

138. Esteller M, Gaidano G, Goodman SN, Zagonel V, Capello D, Botto B, Rossi D, Gloghini A, Vitolo U, Carbone A, Baylin SB, Herman JG: Hypermethylation of the DNA repair gene $\mathrm{O}(6)$-methylguanine DNA methyltransferase and survival of patients with diffuse large B-cell lymphoma. J Natl Cancer Inst 2002, 94:26-32.

139. Hayashi H, Yazawa T, Okudela K, Nagai J, Ito T, Kanisawa M, Kitamura H: Inactivation of O6-Methylguanine-DNA Methyltransferase in human lung adenocarcinoma relates to high-grade histology and worse prognosis among smokers. Jpn J Cancer Res 2002, 93:184-189.

\section{Pre-publication history}

The pre-publication history for this paper can be accessed here: http://www.biomedcentral.com/1471-2407/11/35/prepub

doi:10.1186/1471-2407-11-35

Cite this article as: Brell et al:: O6-Methylguanine-DNA methyltransferase protein expression by immunohistochemistry in brain and non-brain systemic tumours: systematic review and meta-analysis of correlation with methylation-specific polymerase chain reaction. BMC Cancer 2011 11:35. 